\title{
N-Nitrosodimethylamine Formation from Treatment of Seasonally and Spatially Varying Source Water
}

\author{
Maxwell C. Meadows ${ }^{1}$, Soni M. Pradhanang ${ }^{1, *(\mathbb{C})}$, Takahiro Fujioka ${ }^{2} \mathbb{D}$, Hitoshi Kodamatani ${ }^{3}$, \\ Menu B. Leddy ${ }^{4}$ and Thomas B. Boving ${ }^{1}$ (1) \\ 1 Department of Geosciences, University of Rhode Island, Kingston, RI 02881, USA; \\ mcmeadows@uri.edu (M.C.M.); boving@uri.edu (T.B.B.) \\ 2 Graduate School of Engineering, Nagasaki University, Nagasaki 852-8521, Japan; tfujioka@nagasaki-u.ac.jp \\ 3 Division of Earth and Environmental Science, Graduate School of Science and Engineering, Kagoshima \\ University, Kagoshima 890-0065, Japan; kodamatani@gmail.com \\ 4 Essential Environmental \& Engineering Systems, Huntington Beach, CA 92649, USA; menuleddy@gmail.com \\ * Correspondence: spradhanang@uri.edu
}

Received: 6 August 2019; Accepted: 27 September 2019; Published: 28 September 2019

check for updates

\begin{abstract}
N-nitrosodimethylamine (NDMA) is a disinfection by-product (DBP) that has been classified as a probable human carcinogen in multiple risk assessments. NDMA presence in drinking water is widespread and dependent on source water, disinfectant type, precursors, and water treatment strategies. The objectives of this study were to investigate NDMA formation potential in a modeled monochloramine water treatment plant (WTP) fed by seasonally and spatially varying source water; and to optimize DBP precursor removal by combining conventional and additional treatment techniques. After NDMA analysis, it was found that NDMA formation was significantly dependent on source water type and monochloramine contact time (CT); e.g., at $24 \mathrm{~h} \mathrm{CT}$, Cork Brook produced $12.2 \mathrm{ng} / \mathrm{L}$ NDMA and Bailey Brook produced $4.2 \mathrm{ng} / \mathrm{L}$ NDMA, compared with $72 \mathrm{~h} \mathrm{CT}$, Cork Brook produced $4.1 \mathrm{ng} / \mathrm{L}$ NDMA and Bailey Brook produced $3.4 \mathrm{ng} / \mathrm{L}$ NDMA. No correlations were found between traditional DBP precursors such as total organic carbon and total nitrogen, and the formation of NDMA. The laboratory bench-top treatment system was highly effective at removing traditional DBP precursors, highlighting the need for WTPs to alter their current treatment methods to best accommodate the complex system of DBP control.
\end{abstract}

Keywords: NDMA; disinfection by-product formation; source water; natural water; precursors; treatment; water quality

\section{Introduction}

$\mathrm{N}$-nitrosamines are a group of contaminants of emerging concern that may be present in drinking water as by-products from water treatment plant (WTP) operations [1-6]. Significant influences on the formation of $\mathrm{N}$-nitrosamines in drinking water include source water impairment before treatment, e.g., industrial, wastewater, and septic system effluents [6,7]. Presence of N-nitrosamines in drinking water is of particular concern because of their carcinogenic, mutagenic, and teratogenic properties [8,9]. $\mathrm{N}$-nitrosodimethylamine (NDMA, $\mathrm{C}_{2} \mathrm{H}_{6} \mathrm{~N}_{2} \mathrm{O}$ ), and several other $\mathrm{N}$-nitrosamines are classified as probable carcinogens based on domestic and international assessments [10-12]. To date, no United States federal regulatory limits have been established for NDMA and other N-nitrosamines in drinking water, although some states have created their own guidelines, e.g., California and Massachusetts, in 2002 and 2004, respectively [13,14]. Many studies were developed to understand the mechanics of NDMA formation during water treatment [1,2,4,15-17]. However, little research has evaluated 
NDMA formation from the treatment of seasonally and spatially varying source water during normal environmental conditions.

Primary NDMA formation pathways involve reactions between NDMA precursors found in source water, e.g., dimethylamine (DMA) and other dissolved organic nitrogen (DON) species, with the disinfectant used during treatment $[1-4,18,19]$. The degree to which NDMA forms under these conditions is significantly dependent on influent source water, type of disinfectant, $\mathrm{pH}$, and temperature [2,6,19-21]. More specifically, monochloramine, one of the widely used disinfectants in the United States, is documented to be one of the most critical reactants that lead to NDMA formation $[1,4,22,23]$. Potential NDMA precursors such as DON, dissolved organic carbon (DOC), and natural organic matter $(\mathrm{NOM})$ are also significantly influenced by land use and seasonal variations [24-27].

Traditionally, formation of disinfection by-products (DBPs) such as trihalomethanes (THMs) and haloacetic acids (HAAs) can be controlled by removing NOM precursors before disinfection [28-30]. Conventional WTP processes used for removing precursors include coagulation and flocculation, sedimentation, and filtration [31]. Other studies have been conducted to address the impact of using additional filtration techniques for controlling DBP precursors [32,33]. Little information is known about the impact of water treatment processes on potential NDMA precursor removal, and the relationship it has with NDMA formation following monochloramine disinfection.

To address this issue, we investigated the formation potential of NDMA in a modelled chloramination WTP fed by seasonally and spatially varying source water. To enhance the reduction of potential NDMA precursors, conventional water treatment methods were combined with additional filtration techniques. This work will also address the impact of regional WTP operations and their potential to form NDMA under specific treatment scenarios. Results from this study will serve as the foundation for further NDMA research as it relates to drinking water treatment of regionally sourced waters.

\section{Materials and Methods}

\subsection{Field Site Locations}

The field sites identified in Figure 1 were chosen for this study to demonstrate impact of spatial variability on source water quality. Both locations are headwater streams for major reservoirs in Newport and Scituate, Rhode Island. Source water entering Newport WTPs, e.g., Bailey Brook, has received higher loads of nutrients from a variety of sources due to its location in an urban area [34]. Cork Brook, although forested [35], has experienced seasonally high loadings of precursors, particularly during intense precipitation events. It is expected that the different land use activities associated with each field site will produce varying levels of precursors [20,25,27], later affecting the formation of NDMA upon water treatment.

\subsection{Sample Collection}

Samples were collected during Summer 2018 (June-August), Autumn 2018 (SeptemberNovember), and Spring 2019 (March-May) after precipitation events greater than $12.7 \mathrm{~mm}$ [36]. Precipitation during sampling events generated turbid water samples, which captured a flux of targeted precursors such as DOC and DON. During each sampling event at both field sites, one sample was collected in a clean $19 \mathrm{~L}$ plastic jerry can. After collection, samples were returned to the University of Rhode Island Hydrology and Environmental Water Quality Research Laboratory for freezer storage (below $0{ }^{\circ} \mathrm{C}$ ) until sample processing. 


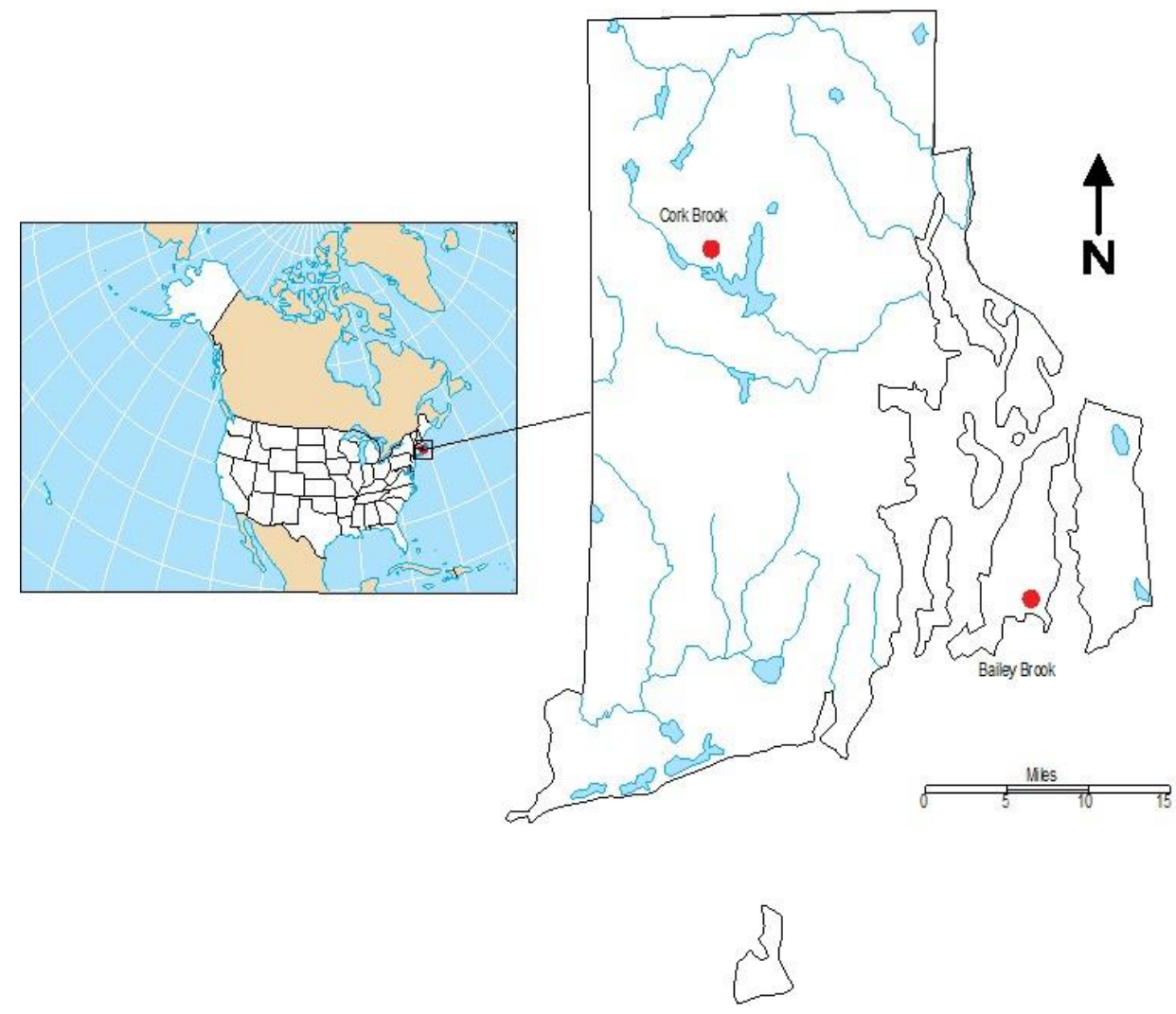

Figure 1. Map of the state of Rhode Island, USA. Field sample locations identified by red circles on map. Rhode Island map to scale.

\subsection{Sample Processing}

Each field sample was processed two times using a laboratory bench-top water treatment system (Figure 2) to simulate water treatment and distribution at a municipal or metropolitan scale. Flocculation, coagulation, and sedimentation phases of water treatment were achieved using a Lovibond ET 750 Floc Tester, equipped with $2 \mathrm{~L}$ Phipps \& Bird square B-Ker². Beakers were filled to the $2 \mathrm{~L}$ mark with thawed sample, then dosed with $25 \mathrm{mg} / \mathrm{L}$ of ferric sulfate $\left(\mathrm{Fe}_{2}\left(\mathrm{SO}_{4}\right)_{3}\right)$ (ferrous iron $0.0 \%-0.3 \%$, ferric iron $12.5 \%-13.5 \%)$. To achieve optimal flocculation with the $\mathrm{Fe}_{2}\left(\mathrm{SO}_{4}\right)_{3}, \mathrm{pH}$ was adjusted to 5.6 using 1 $\mathrm{M}$ laboratory grade sulfuric acid. Floc Tester blade height was adjusted to $57.15 \mathrm{~mm}$ from the bottom of the beaker, then mixed at $250 \mathrm{rpm}$ for $10 \mathrm{~min}$. After allowing floc to settle for $30 \mathrm{~min}$, the sample was mixed at $30 \mathrm{rpm}$ for $30 \mathrm{~min}$, then settled for at least $1 \mathrm{~h}$. Using a Fisher Scientific Variable Flow peristaltic pump, water above the settled particulate layer was pumped through acrylic tubing (37 $\mathrm{mm}$ o.d. $\times 31 \mathrm{~mm}$ i.d., $420 \mathrm{~mm}$ length) filled with beds of $0.45-0.55 \mathrm{~mm}$ homogenized silica sand (100 mm length), and 0.95-1.05 mm cleaned anthracite (200 mm length), under-bedded by $6.35 \mathrm{~mm}$ washed gravel (60 mm lengths). A Cole-Parmer Gear Pump Drive peristaltic pump was used to pump effluent from the dual-media column filter into a borosilicate glass column ( $25 \mathrm{~mm}$ i.d., $300 \mathrm{~mm}$ length) filled with 20-40 mesh granular activated carbon (GAC). Addition of the GAC column filter to the treatment system was to enhance precursor removal before disinfection. Both filtration columns were selected to have an empty bed contact time (EBCT) of 10 min [32]. During each run of processing, two samples were collected in $500 \mathrm{~mL}$ amber glass jars with no headspace from raw water influent and post-filtration effluents, and one sample was collected in a $300 \mathrm{~mL}$ amber glass jar from the same influent and effluents. All processed samples were kept in refrigerator storage $\left(4^{\circ} \mathrm{C}\right)$ until disinfection. 


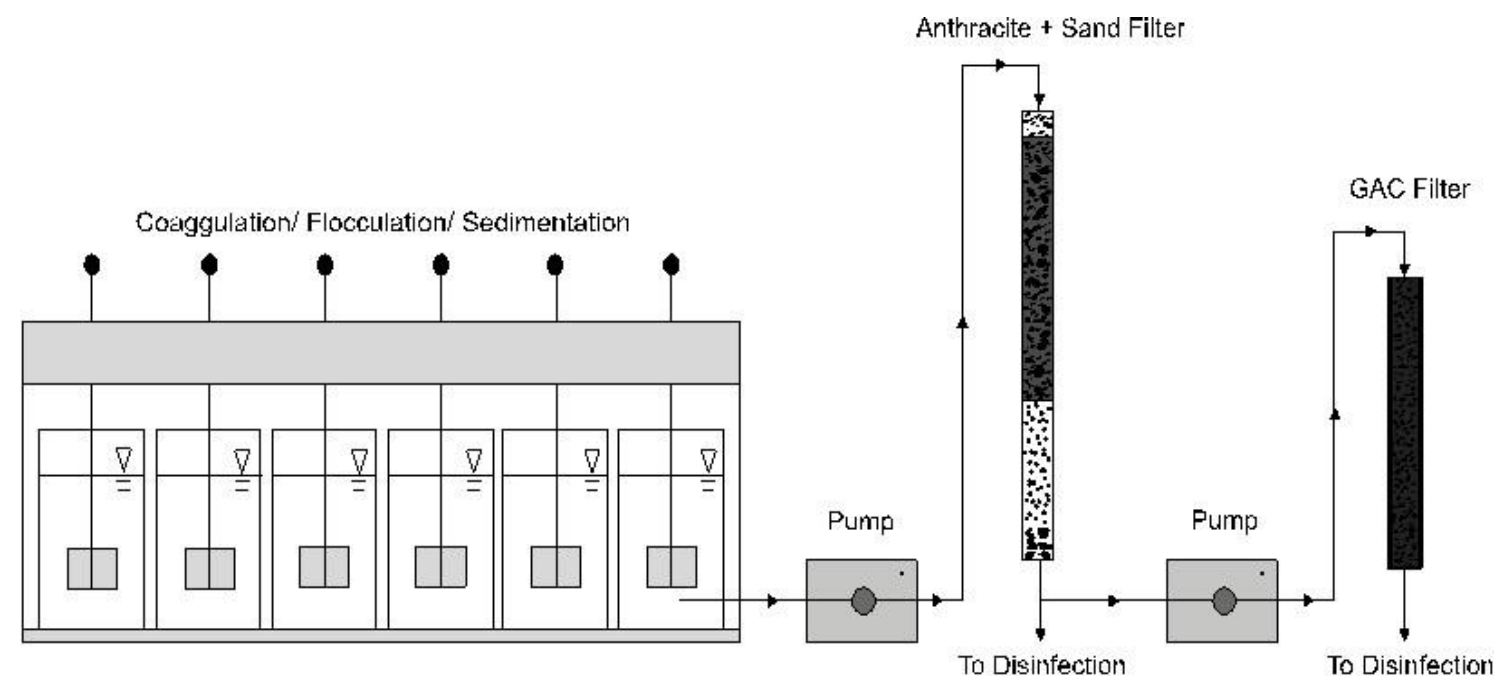

Figure 2. Flow-scheme of bench-top water treatment system.

\subsection{Monochloramine Disinfection}

All $500 \mathrm{~mL}$ processed samples were removed from refrigeration and brought to room temperature $\left(25^{\circ} \mathrm{C}\right)$, then $\mathrm{pH}$ was measured and adjusted to between 9 and 10 using $1 \mathrm{M}$ laboratory grade sodium hydroxide $(\mathrm{NaOH})$. Pre-formed monochloramine $\left(\mathrm{NH}_{2} \mathrm{Cl}\right)$ stock solution was prepared from diluted solutions of sodium hypochlorite $(\mathrm{NaOCl})$ and ammonium chloride $\left(\mathrm{NH}_{4} \mathrm{Cl}\right)$. The $\mathrm{Cl}_{2} / \mathrm{N}$ ratio was 1:1.2, and $\mathrm{pH}$ was adjusted to between 8 and 9 with $1 \mathrm{M}$ laboratory grade $\mathrm{NaOH}$ to prevent the decay of $\mathrm{NH}_{2} \mathrm{Cl}$ into dichloramine $\left(\mathrm{NHCl}_{2}\right)$ and trichloramine $\left(\mathrm{NCl}_{3}\right)$ from excess free chlorine, and low $\mathrm{pH}$ values $[29,37]$. The stock solution was aged in $1 \mathrm{~L}$ amber jars with no headspace for $1 \mathrm{~h}$ in darkness at $25^{\circ} \mathrm{C}$, to guarantee complete $\mathrm{NH}_{2} \mathrm{Cl}$ formation. Stock solutions were freshly prepared before sample disinfection, and monochloramine dose accuracy was tested using a HACH SL 1000 probe. The $\mathrm{NH}_{2} \mathrm{Cl}$ stock solution was injected into each processed sample to achieve a simulated water treatment dose of $4 \mathrm{mg} / \mathrm{L} \mathrm{NH}{ }_{2} \mathrm{Cl}$. Once dosed with $\mathrm{NH}_{2} \mathrm{Cl}$, samples were aged to an allotted contact time (CT) of 24 or $72 \mathrm{~h}$ in the dark, at $25^{\circ} \mathrm{C}$. After disinfection $\mathrm{CT}$ was achieved, $\mathrm{NH}_{2} \mathrm{Cl}$ residuals were measured using a HACH SL 1000 probe, and then samples were quenched with $100 \mathrm{mg}$ sodium thiosulfate anhydrous.

\subsection{NDMA Analysis Preparation}

Disinfected samples were filtered using GE Whatman $0.45 \mu \mathrm{m}$ sterile PTFE filters. About $1 \mathrm{~mL}$ of disinfected sample was filtered directly into clear, sterile $2 \mathrm{~mL}$ vials. All sample vials were immediately packed into an insulated cooler with freezer packs, then express-shipped to Kagoshima University, Japan for NDMA analysis.

\subsection{Analytical Techniques}

\subsubsection{Precursor Analysis}

Precursors selected for this experiment were total organic carbon (TOC) and total nitrogen (TN). The precursors were analyzed using a Shimadzu TOC-L/TN-M unit equipped with an OCT-L autosampler. $1 \mathrm{M}$ TOC and TN stock solutions were prepared from potassium hydrogen phthalate $\left(\mathrm{C}_{8} \mathrm{H}_{5} \mathrm{KO}_{4}\right)$ and potassium nitrate $\left(\mathrm{KNO}_{3}\right)$. Calibration standard was prepared by combining $0.1 \mathrm{M}$ $\mathrm{KNO}_{3}, 0.1 \mathrm{M} \mathrm{C}_{8} \mathrm{H}_{5} \mathrm{KO}_{4}$, and $0.05 \mathrm{M}$ hydrochloric acid $(\mathrm{HCl})$. Serial dilutions of calibration standard were prepared to meet the needs of the expected TOC and TN concentration range. The analytical method performed simultaneous analysis of TOC and TN. 


\subsubsection{NDMA Analysis}

Concentrations of NDMA were analyzed and determined using a high-performance liquid chromatography-inline anion exchange reaction-photochemical reaction-chemiluminescence (HPLC-AEM-PR-CL) [38,39]. The description below was adopted from [40] for a concise explanation of the applied analytical technique:

(1) Separation of NDMA with an octadecylsilyl column as part of high-performance liquid chromatography (HPLC)

(2) Photolysis of NDMA with UV light irradiation to form peroxynitrite

(3) Chemiluminescence detection of peroxynitrite with luminol solution.

The analytical system consisted of LC-10ADvp HPLC pumps (Shimadzu, Kyoto, Japan), an SIL-20AC autosampler (Shimadzu); an AEM module (Nichiri Mfg., Chiba, Japan); an AEM-PR control unit equipped with a peristaltic pump dedicated for the AEM washing solution and two inline degassers (Nichiri Mfg., Chiba, Japan), a CTO-10ACvp column oven (Shimadzu) containing the AEM, a PR and an InertSustain C18-AQ column ( $5 \mu \mathrm{m}, 250 \mathrm{~mm}$ length; $4.6 \mathrm{~mm}$ i.d., GL sciences, Tokyo, Japan); a CL-2027plus CL detector (JASCO, Tokyo, Japan); and a Chromato-PRO data processor (Runtime Instruments, Kanagawa, Japan). The photochemical reactor installed in the column oven was equipped with a low-pressure mercury lamp (OFS-221XB, Miyata Elevam Inc., Yokohama, Japan) and reaction coil made of PTFE tube $\left(1 / 16^{\prime \prime}\right.$ o.d. $\times 0.5 \mathrm{~mm}$ i.d., active length $\left.=100 \mathrm{~cm}\right)$ in an aluminum tube [39].

\subsection{Statistical Methods}

All statistical analysis was completed using OriginPro software. Box plots and scatter plots were generated to demonstrate precursor removal and NDMA formation. Main and interaction effects on the concentrations of NDMA, TOC, and TN were assessed using three-way ANOVA. The three-way analysis of variance model can be written as:

$$
\mathrm{Y}_{\mathrm{ijkt}}=\mu+\alpha_{\mathrm{i}}+\beta_{\mathrm{j}}+\gamma_{\mathrm{k}}+(\alpha \beta)_{\mathrm{ij}}+(\alpha \gamma)_{\mathrm{ik}}+(\beta \gamma)_{\mathrm{jk}}+(\alpha \beta \gamma)_{\mathrm{ijk}}+\varepsilon_{\mathrm{ijkt}}
$$

where the magnitude of any observation $Y_{i j k t}$ can be affected by several possible influences. $\mu$ is the overall mean, $\alpha_{i}$ is the influence of the $i^{\text {th }}$ category of the column variable, $\beta_{j}$ is the influence of the $j^{\text {th }}$ category of the column variable, and $\gamma_{\mathrm{k}}$ is the influence of the $\mathrm{k}^{\text {th }}$ category of the column variable. Interaction effects from the combination of column variables are denoted by terms $(\alpha \beta)_{\mathrm{ij}},(\alpha \gamma)_{\mathrm{ik}}$, and $(\beta \gamma)_{\mathrm{jk}}$. The term $(\alpha \beta \gamma)_{\mathrm{ijk}}$ is called a three-way interaction term, and $\varepsilon_{\mathrm{ijkk}}$ is the residual error term.

Significance level $\alpha=0.05$ was set for all calculations to define the probability of concluding that a difference between groups exists when there is no actual difference. Limitations of ANOVA excluded a fourth main effect from the analysis. Adjusting for this confine, separate ANOVA tables were generated to represent NDMA formed from treatment of the two source waters.

\section{Results and Discussion}

\subsection{NDMA Formation}

This study was designed to model the formation of NDMA from treatment of local source waters using chloramine water treatment techniques. The aim behind the study design was to demonstrate that if local WTPs used chloramine as a primary disinfectant, then the product water sent into distribution would contain low levels of NDMA. Seasonal and spatial variations were considered as possible effects, and precursor removal before disinfection was also considered. Based on previous NDMA formation potential studies, it was expected that after longer monochloramine CT higher concentrations of NDMA would form $[19,22,23,41]$.

Bailey Brook and Cork Brook field samples were collected during three seasons (Summer, Autumn, Spring) and the field samples were treated using a laboratory bench-top treatment system. To capture 
the effects of seasonal and spatial variation on the formation of NDMA during water treatment, NDMA data was generated into boxplots per each sampling event, regardless of where the NDMA data originated in the bench-top treatment system, e.g., raw water influent (R), post-dual-media filtration effluent $(\mathrm{F})$, and post-dual-media filtration + GAC filtration effluent. Using this approach, we found that only Cork Brook produced higher concentrations of NDMA during the first $24 \mathrm{~h}$ of $\mathrm{CT}$ when compared to the $72 \mathrm{~h} \mathrm{CT}$ (Figure 3). Exhaustion of NDMA precursors by other DBPs is a possibility given that residual chloramine decreased consistently over $72 \mathrm{~h}$; however, it is speculated that if exhaustion were to occur, there would not be an increase of NDMA in the Cork Brook $24 \mathrm{~h} C T$ samples [42].

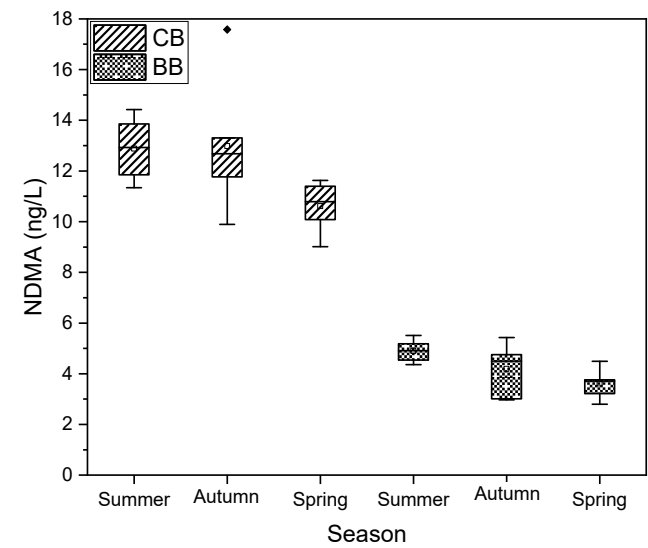

(a)

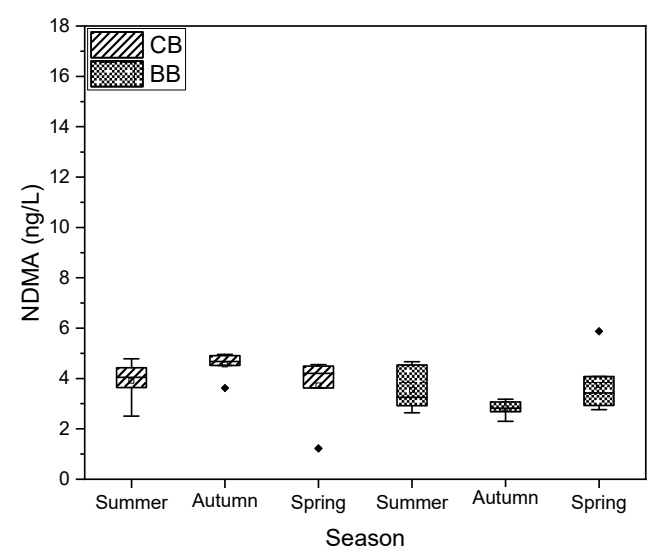

(b)

Figure 3. NDMA concentrations in product water after (a) $24 \mathrm{~h}$ monochloramine CT, and (b) $72 \mathrm{~h}$ monochloramine CT, corresponding to sample site and season. Plots based off of all NDMA concentrations regardless of where the sample was collected from the treatment system. $\mathrm{CB}=\mathrm{Cork}$ Brook, BB = Bailey Brook.

There was a substantial difference in average NDMA formed between Cork Brook (12.2 ng/L) and Bailey Brook (4.2 ng/L) in the $24 \mathrm{~h} \mathrm{CT}$ samples (Figure 3a); however, the difference between the two averages noticeably decreased in the $72 \mathrm{~h} \mathrm{CT} \mathrm{samples} \mathrm{(Figure} \mathrm{3b).} \mathrm{This} \mathrm{effect} \mathrm{could} \mathrm{be} \mathrm{explained}$ by NDMA precursors being site-specific and influenced by several factors [43-46]. To determine the processes leading to NDMA reduction over longer $\mathrm{CT}$, further studies are required. It is also noteworthy that the $72 \mathrm{~h}$ CT samples still produced higher average levels of NDMA in Cork Brook $(4.1 \mathrm{ng} / \mathrm{L})$ than Bailey Brook (3.4 ng/L), suggesting that the precursors associated with NDMA formation are more frequently associated with forested areas rather than areas of urban influence [47-51].

In previous NDMA formation studies, known precursors were used as reactants with varying doses of monochloramine, resulting in increasing NDMA concentrations with respect to time $[19,22,23,41]$. The results described in this study are contradictory to traditional NDMA formation potential theory but are best justified by the experimental design. The experimental approach focused on using natural environmental water with potentially very low concentrations of NDMA precursors. Although the results are specific to Rhode Island based source water, they are not representative of all other North East United States source water, therefore, further studies are required to understand NDMA formation potential at other regional locations.

\subsection{Seasonal Precursor Presence}

To capture seasonal influence on concentrations of TOC and TN, boxplots were generated for both TOC and TN per each sampling event as indicated in 3.1. NDMA Formation. Findings from this analysis objective show that seasonal influence on TOC and TN concentrations was substantial (Figure 4). However, TOC and TN concentrations had no apparent effect on the formation of NDMA (Figure 5). 
This finding supports claims that no significant relationships exist between NDMA and dissolved organic carbon (DOC), natural organic matter (NOM), or TN, and provides further evidence that NDMA has a very complex formation pathway [41,43-45]. The NDMA precursor fingerprinting study by [46] explained that certain aliphatic, as well as peptide and lipid-like compounds are responsible for the majority of NDMA formation in natural waters, and the origin of those constituents is likely from wastewater effluents. The likelihood that both Cork Brook and Bailey Brook source water is being impacted by wastewater effluent is low, therefore creating a need for future investigation into precursor identification at the selected field sites.

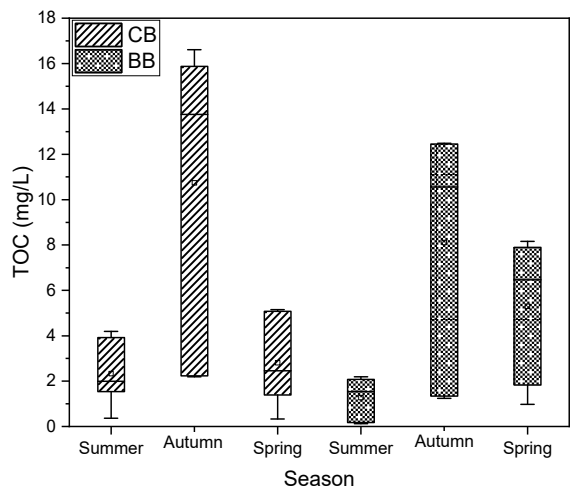

(a)

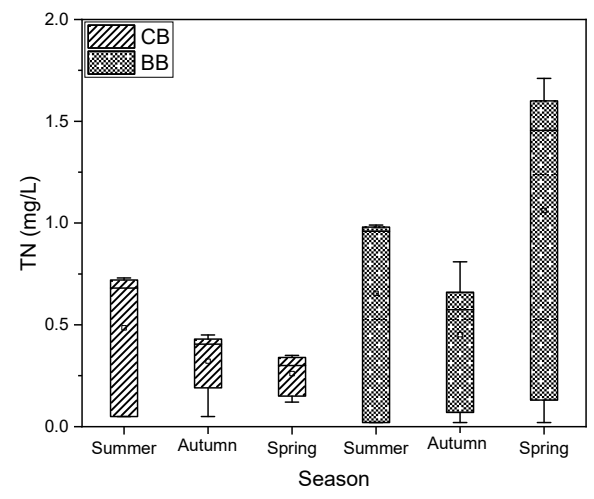

(b)

Figure 4. (a) TOC, and (b) TN concentrations of processed samples before disinfection, corresponding to sample site and season. Plots based off of all TOC and TN concentrations regardless of where the sample was collected from the treatment system. $\mathrm{CB}=$ Cork Brook, BB = Bailey Brook.

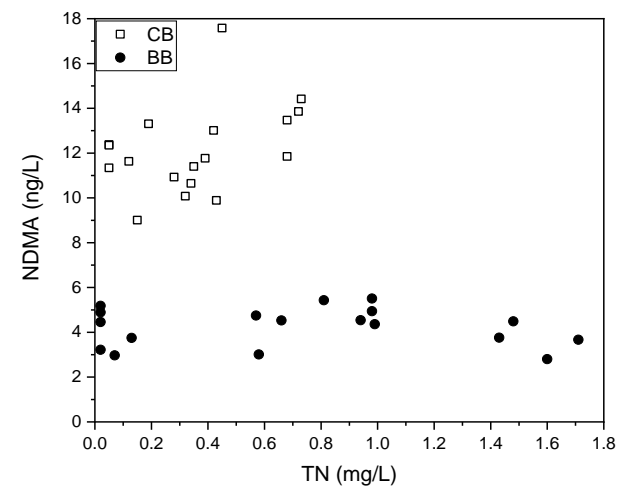

(a)

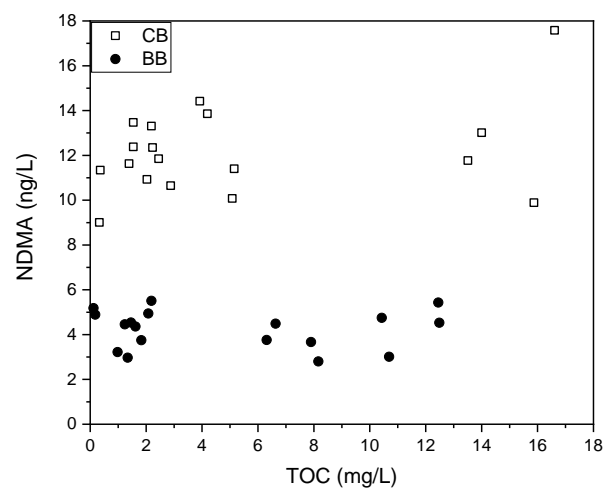

(c)

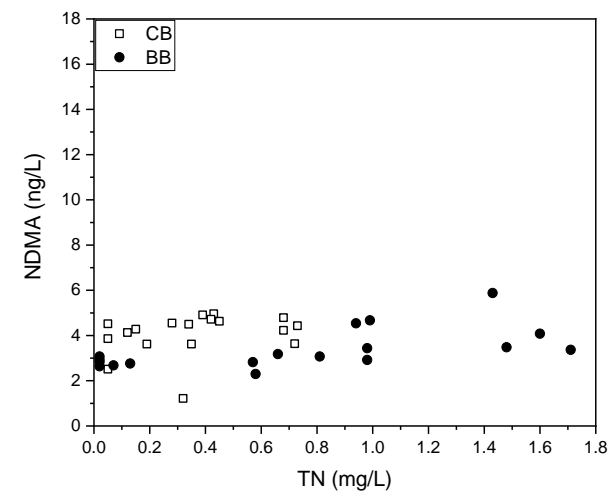

(b)

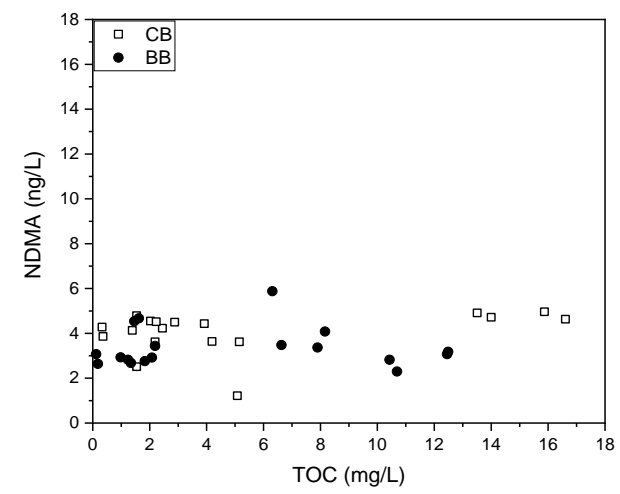

(d)

Figure 5. Scatter plots showing no relationships between TN and NDMA, and TOC and NDMA. $(\mathbf{a}, \mathbf{c})=24 \mathrm{~h} \mathrm{CT} ;(\mathbf{b}, \mathbf{d})=72 \mathrm{~h}$ CT. CB = Cork Brook, BB = Bailey Brook. 


\subsection{Evaluation of Bench-Top Treatment Efficacy}

\subsubsection{Precursor Removal}

In order to assess bench-top treatment system efficacy, precursor concentrations were quantified in samples collected from three main points in the system, e.g., R, F, and GAC. At alpha level of 0.05, Figure 6 shows significant differences in precursors concentrations as source water passes through the treatment system. Also noted in Figure 6, there is a negative correlation between the precursors concentration and the place in the treatment system where the sample was collected, demonstrating that the bench-top system was effective at removing traditional DBP precursors $[52,53]$. The addition of a GAC column filter following dual-media filtration proved to be highly effective at reducing TOC and $\mathrm{TN}$ concentrations by $85 \%$ and $86 \%$, respectively.

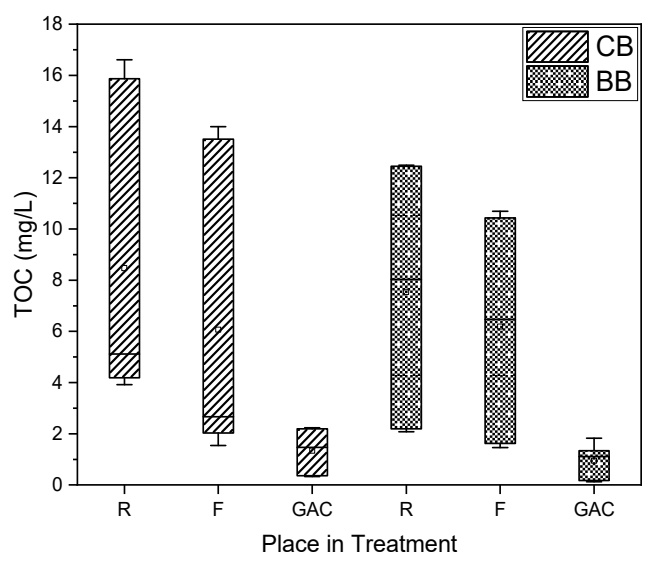

(a)

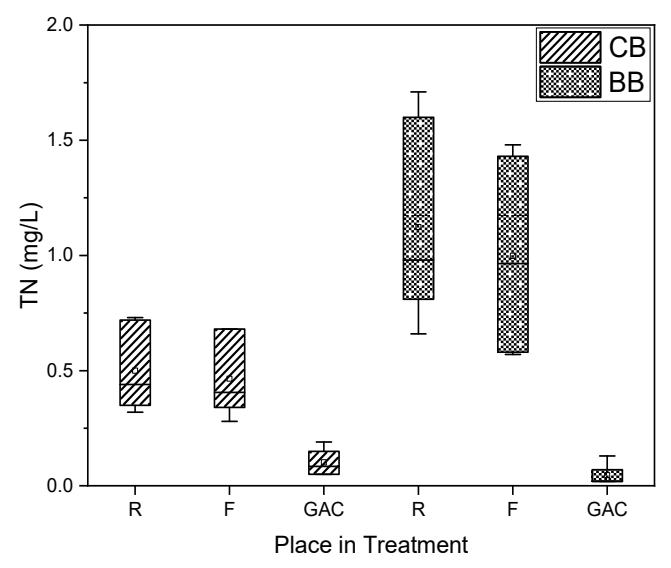

(b)

Figure 6. (a) TOC, and (b) TN precursor concentrations of processed samples, corresponding to the sample's position in the treatment system. Samples were collected at three major phases during treatment: $\mathrm{R}=$ untreated raw water; $\mathrm{F}=$ dual-media filtration effluent; $\mathrm{GAC}=$ dual media filtration + GAC filtration effluent. Plots based off of all TOC and TN concentrations regardless of seasonal sampling event. $\mathrm{CB}=$ Cork Brook, $\mathrm{BB}=$ Bailey Brook.

\subsubsection{NDMA Formation Potentials}

Although there were significant differences in precursor concentrations throughout the treatment system (Figure 6), there was no apparent relationship with the formation of NDMA at each of the main sampling points of the system: R, F, GAC (Figure 7). Therefore, it cannot be stated that the removal of TOC and TN during water treatment will ultimately reduce the likelihood of forming NDMA during chloramination. For an improved assessment of targeting NDMA forming precursors, future studies are required to determine the chemical composition of the sample water during each of the main phases of the treatment procedure. Comparisons were made with other studies to identify which particular groups of precursors were influencing the reactions that generated NDMA (Table 1). The most significant finding was that NDMA formation has a strong positive correlation with aliphatic, as well as peptide and lipid-like compounds [46]. Since the presence of the aforementioned group of precursors is frequently associated with wastewater impacts [46], other routes of exposure were considered. 


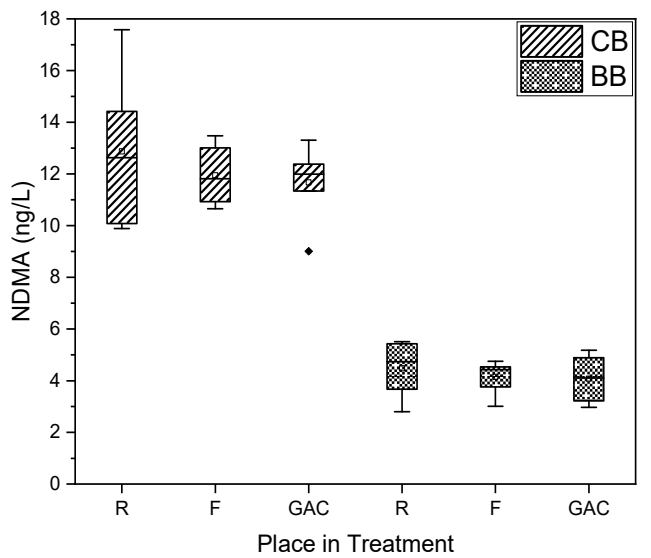

(a)

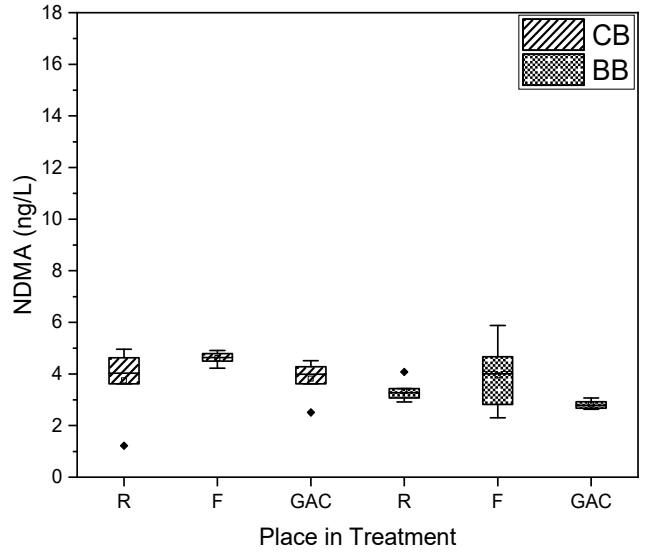

(b)

Figure 7. NDMA concentrations in product water after (a) $24 \mathrm{~h}$ monochloramine CT, and (b) $72 \mathrm{~h}$ monochloramine CT. Samples were collected at three major phases during treatment: $\mathrm{R}=$ untreated raw water; $\mathrm{F}=$ dual-media filtration effluent; GAC = dual media filtration + GAC filtration effluent. Plots based off of all NDMA concentrations regardless of seasonal sampling event. CB = Cork Brook, $\mathrm{BB}=$ Bailey Brook.

Table 1. Study comparison on NDMA precursors and their impact on NDMA formation during water treatment.

\begin{tabular}{|c|c|c|c|}
\hline Study & Source Water & Result & Author \\
\hline $\begin{array}{l}\text { NDMA precursors in } \\
\text { natural water }\end{array}$ & $\begin{array}{l}\text { Natural waters from } \\
\text { reservoirs, lakes, and } \\
\text { groundwaters (U.S.) }\end{array}$ & $\begin{array}{l}\text { NDMA formation has weak } \\
\text { correlation to DOC content }\left(\mathrm{R}^{2}=\right. \\
0.41) \text {, however strength of } \\
\text { correlation is source dependent. } \\
\text { NDMA precursors are a suite of } \\
\text { compounds associated with } \\
\text { humic substances and other high } \\
\text { molecular weight polymers }\end{array}$ & [41] \\
\hline $\begin{array}{l}\text { NDMA formation in } \\
\text { water and wastewater }\end{array}$ & $\begin{array}{l}\text { Untreated natural } \\
\text { water (U.S.) }\end{array}$ & $\begin{array}{l}\text { No significant relationship } \\
\text { between NDMA formation and } \\
\text { natural organic carbon or nitrogen }\end{array}$ & [43] \\
\hline $\begin{array}{l}\text { NDMA survey of } \\
\text { drinking water } \\
\text { distribution systems }\end{array}$ & $\begin{array}{c}\text { Lakes, rivers, creeks, and } \\
\text { groundwater (Canada) }\end{array}$ & $\begin{array}{l}\text { No apparent trends between } \\
\mathrm{NDMA} \text { concentrations and DOC, } \\
\mathrm{NH}_{3}-\mathrm{N}, \mathrm{NO}_{3}^{-} \text {, total Kjedldahl } \\
\text { nitrogen }(\mathrm{TKN}) \text {, and organic } \mathrm{N}\end{array}$ & [44] \\
\hline $\begin{array}{l}\text { NDMA formation in } \\
\text { natural water }\end{array}$ & $\begin{array}{l}\text { Rivers and lakes } \\
\text { (U.S. \& Canada) }\end{array}$ & $\begin{array}{l}\text { No significant relationships } \\
\text { between NDMA formation and } \\
\text { total organic carbon (TOC) }\end{array}$ & [45] \\
\hline $\begin{array}{l}\text { NDMA formation in } \\
\text { natural water, and } \\
\text { precursor fingerprinting }\end{array}$ & $\begin{array}{c}\text { Natural } \\
\text { reservoirs (Spain) }\end{array}$ & $\begin{array}{l}\text { After fingerprinting dissolved } \\
\text { organic matter (DOM), a positive } \\
\text { correlation was found between } \\
\text { NDMA formation and aliphatic as } \\
\text { well as peptide and lipid-like } \\
\text { compounds }\left(\mathrm{r}^{2}=0.88\right)\end{array}$ & {$[46]$} \\
\hline
\end{tabular}

The findings from $[54,55]$ state that DOM from forested regions has constituents of hydrophobic and hydrophilic fractions, where the hydrophilic fractions could be composed of carbohydrates, small carboxylic acids, free proteins and peptides. Since NDMA formation was highest in source water collected from the forested watershed during all seasons, it suggests that the findings from $[46,54,55]$ have potentially identified the most influential group of NDMA precursors in this experiment. 
Furthermore, since this particular group of precursors is hydrophilic, there is possible justification as to why the bench-top treatment system was ineffective at NDMA precursor removal, even with the addition of a GAC column.

\subsubsection{Acceptable NDMA Concentrations}

NDMA formed as a by-product from the bench-top water treatment system varied significantly with changing CT (Figure 3). There were also significant differences in NDMA produced from each source water site during both CTs (Tables 2 and 3). Interestingly, source water from Cork Brook produced elevated levels of NDMA (9.1-17.6 ng/L) at $24 \mathrm{~h}$ CT during each of the seasonal sampling events (Figure 3a). However, at $72 \mathrm{~h} \mathrm{CT}$, both Cork Brook and Bailey Brook produced NDMA levels that fell within the same range (1.2-5.8 ng/L) (Figure 3b). At this time, it is unclear as to why Cork Brook produced increased NDMA concentrations at $24 \mathrm{~h} \mathrm{CT}$, then decreased concentrations at $72 \mathrm{~h}$. No published literature accounts for NDMA formation and degradation during chloramination.

Table 2. ANOVA table comparing the main- and interaction effects of treatment (R, F, GAC), CT, and season on the formation of NDMA in Bailey Brook source water.

\begin{tabular}{ccc}
\hline Effect & Mean Square & $P$ Value \\
\hline Treatment & 1.195 & 0.085 \\
CT & 6.769 & 0.000 \\
Season & 1.700 & 0.035 \\
Treatment * CT & 1.003 & 0.120 \\
Treatment * Season & 0.855 & 0.133 \\
CT * Season & 2.260 & 0.015 \\
Treatment ${ }^{*}$ CT * Season & 0.684 & 0.211 \\
\hline
\end{tabular}

${ }^{*}$ Estimate of population variance based on the variability among a given set of measures.

Table 3. ANOVA table comparing the main and interaction effects of treatment (R, F, GAC), CT, and season, on the formation of NDMA in Cork Brook source water.

\begin{tabular}{ccc}
\hline Effect & Mean Square & $P$ Value \\
\hline Treatment & 1.218 & 0.601 \\
CT & 590.571 & 0.000 \\
Season & 8.471 & 0.047 \\
Treatment * CT & 2.549 & 0.356 \\
Treatment * Season & 1.638 & 0.600 \\
CT * Season & 3.471 & 0.252 \\
Treatment ${ }^{*}$ CT ${ }^{*}$ Season & 0.271 & 0.975 \\
\hline
\end{tabular}

${ }^{*}$ Estimate of population variance based on the variability among a given set of measures.

Drinking water leaving a WTP is typically pumped to a storage facility where it resides for days before reaching the consumer [56]. For the case of NDMA formation potential in Rhode Island based source water (Figure 1), these findings are essential. In this experiment, both source waters exposed to $72 \mathrm{~h}$ monochloramine CT resulted in NDMA concentrations below $10 \mathrm{ng} / \mathrm{L}$, complying with international guidelines, and regulatory limits established by California and Massachusetts [12-14]. Furthermore, the use of a dual-media filter and a GAC filter had no effect on reducing NDMA formation potential during water treatment, however NDMA concentrations were still below $10 \mathrm{ng} / \mathrm{L}$ after 72 $\mathrm{h}$ CT for both Bailey Brook and Cork Brook source water. With the information provided by this study, and future NDMA formation potential tests of the selected source waters, Rhode Island based WTPs may consider switching to chloramine disinfection to comply with established DBP regulations effectively, and N-DBP regulations, to come in the near future. 


\section{Conclusions and Future Work}

We developed and used a laboratory bench-top water treatment system to determine how NDMA formation is influenced by the treatment of seasonally and spatially varying source water. Addressing the influences of precursor interaction with monochloramine disinfectant, we found that the proposed precursors, TOC and TN, had no direct relationship with the formation of NDMA. However, it was noted that the NDMA-forming precursors are source water dependent and are found particularly in forested watersheds. Also, the precursors that led to the formation of NDMA were not impacted by the bench-top treatment system, suggesting they are likely hydrophilic compounds. CT appeared to be a significant variable when discussing the formation of NDMA, as $72 \mathrm{~h} \mathrm{CT}$ led to lower levels of NDMA when compared to $24 \mathrm{~h} \mathrm{CT}$. In fact, the levels of NDMA formed after $72 \mathrm{~h}$ of CT were below regulatory guidelines (10 ng/L) established by California and Massachusetts. This finding suggests that if Rhode Island WTPs were to switch to monochloramine as a primary disinfectant during water treatment, there would be low risk of exposing consumers to harmful levels of NDMA and other DBPs. Although this particular result is contradictory to traditional NDMA formation potential theory, further studies addressing NDMA reduction with respect to $\mathrm{CT}$ would be highly beneficial.

Although the bench-top treatment system was ineffective at removing NDMA precursors, it was highly effective at removing traditional DBP precursors such as TOC and TN. The addition of a GAC column filter proved to reduce levels of TOC and TN by $85 \%$ and $86 \%$, respectively. Additions or improvements must be made to the bench-top treatment system to reduce levels of influential NDMA precursors. In future studies, implementing other water treatment practices such as membrane filtration, ozone, and UV disinfection should be considered. A supplemental fingerprinting study would also prove beneficial for determining the extent of NDMA precursors in Rhode Island and other regional source waters.

Author Contributions: M.C.M., S.M.P., and T.B.B. conceived and designed the experiments; M.C.M. performed the experiments; T.F. and H.K. generated the NDMA data; M.C.M. and S.M.P. analyzed the data; M.C.M. and M.B.L. wrote the paper.

Funding: This research was funded by RI-WRC 2017, S-1063 USDA Multistate Hatch, and Rhode Island HUD 6045.

Acknowledgments: A special thank you to Hichem Hadjeres for his help in the field and experiment designs. We would also like to thank Brendan McCarron and Alexandra Duryea for their help in operating the bench-top water treatment system.

Conflicts of Interest: The authors declare no conflict of interest.

\section{References}

1. Choi, J.; Valentine, R.L. Formation of N-nitrosodimethylamine (NDMA) from reaction of monochloramine: A new disinfection by-product. Water Res. 2002, 36, 817-824. [CrossRef]

2. Mitch, W.A.; Sedlak, D.L. Formation of N-nitrosodimethylamine (NDMA) from dimethylamine during chlorination. Environ. Sci. Technol. 2002, 36, 588-595. [CrossRef] [PubMed]

3. Choi, J.; Valentine, R.L. N-nitrosodimethylamine formation by free-chlorine-enhanced nitrosation of dimethlyamine. Environ. Sci. Technol. 2003, 37, 4871-4876. [CrossRef] [PubMed]

4. Schreiber, I.M.; Mitch, W.A. Nitrosamine formation pathway revisited: The importance of chloramine speciation and dissolved oxygen. Environ. Sci. Technol. 2006, 40, 6007-6014. [CrossRef] [PubMed]

5. Krasner, S.W. The formation and control of emerging disinfection by-products of health concern. Philos. Trans. R. Soc. A 2009, 367, 4077-4095. [CrossRef] [PubMed]

6. Nawrocki, J.; Andrzejewski, P. Nitrosamines and water. J. Hazard. Mater 2011, 189, 1-18. [CrossRef]

7. Wolff, I.A.; Wasserman, A.E. Nitrates, nitrites, and nitrosamines. Science 1972, 177, 15-19. Available online: http://www.jstor.org/stable/1733909 (accessed on 27 March 2018). [CrossRef] [PubMed]

8. Lin, J.K. Nitrosamines as potential environmental carcinogens in man. Clin. Biochem. 1990, 23, 67-71. [CrossRef]

9. Loeppky, R.N. Nitrosamine and N-nitroso compound chemistry and biochemistry. Am. Chem. Soc. 1994, 1-18. [CrossRef] 
10. U.S. EPA. Guidelines for Carcinogen Risk Assessment; Federal Register: Washington, DC, USA, 1986; pp. $22-58$.

11. IARC. Evaluation of the Carcinogenic Risks to Humans; IARC Monographs: Lyon, France, 1987; Volume 7, pp. 1-449. [CrossRef]

12. WHO. Guidelines for Drinking-Water Quality; WHO: Geneva, Switzerland, 2017; Volume 4, pp. 1-541.

13. A Brief History of NDMA Findings in Drinking Water. Available online: http://www.waterboards.ca.gov/ drinking_water/certlic/drinkingwater/NDMAhistory.html (accessed on 27 August 2018).

14. Drinking Water Standards and Guidelines. Available online: https://www.mass.gov/guides/drinking-waterstandards-and-guidelines (accessed on 7 August 2018).

15. Mitch, W.A.; Sedlak, D.L. Characterization and fate of N-nitrosodimethylamine precursors in municipal wastewater treatment plants. Environ. Sci. Technol. 2004, 38, 1445-1454. [CrossRef] [PubMed]

16. Schreiber, I.M.; Mitch, W.A. Influence of the order of reagent addition on NDMA formation during chloramination. Environ. Sci. Technol. 2005, 39, 3811-3818. [CrossRef] [PubMed]

17. Kemper, J.M.; Walse, S.S.; Mitch, W.A. Quaternary amines as nitrosamine precursors: A role for consumer products? Environ. Sci. Technol. 2010, 44, 1224-1231. [CrossRef] [PubMed]

18. Lee, W.; Westerhoff, P.; Croué, J. Dissolved organic nitrogen as a precursor for chloroform, dichloroacetonitrile, N-nitrosodimethylamine, and trichloronitromethane. Environ. Sci. Technol. 2007, 41, 5485-5490. [CrossRef] [PubMed]

19. Chang, H.; Chen, C.; Wang, G. Identification of potential nitrogenous organic precursors for C-, N-DBPs and characterization of their DBPs formation. Water Res. 2011, 45, 3753-3764. [CrossRef] [PubMed]

20. Tong, S.T.Y.; Chen, W. Modeling the relationship between land use and surface water quality. J. Environ. Manag. 2002, 66, 377-393. [CrossRef]

21. Mitch, W.A.; Gerecke, A.C.; Sedlak, D.L. A N-Nitrosodimethylamine (NDMA) precursor analysis for chlorination of water and wastewater. Water Res. 2003, 37, 3733-3741. [CrossRef]

22. Chen, Z.; Valentine, R.L. Modeling the formation of N-nitrosodimethylamine (NDMA) from the reaction of natural organic matter (NOM) with monochloramine. Environ. Sci. Technol. 2006, 40, 7290-7297. [CrossRef]

23. Selbes, M.; Beita-Sandí, W.; Kim, D.; Karanfil, T. The role of chloramine species in NDMA formation. Water Res. 2018, 140, 100-109. [CrossRef]

24. Brisson, I.J.; Levallois, P.; Tremblay, H.; Sérodes, J.; Deblois, C.; Charrois, J.; Taguchi, V.; Boyd, J.; Li, X.; Rodriguez, M.J. Spatial and temporal occurrence of N-nitrosamines in seven drinking water supply systems. Environ. Monit. Assess. 2013, 185, 7693-7708. [CrossRef]

25. Uzun, H.; Kim, D.; Karanfil, T. Seasonal and temporal patterns of NDMA formation potentials in surface waters. Water Res. 2015, 69, 162-172. [CrossRef]

26. Bei, E.; Liao, X.; Meng, X.; Li, S.; Wang, J.; Sheng, D.; Chao, M.; Chen, Z.; Zhang, X.; Chen, C. Identification of nitrosamine precursors from urban drainage during storm events: A case study in southern China. Chemosphere 2016, 160, 323-331. [CrossRef] [PubMed]

27. Vaughan, M.C.H.; Bowden, W.B.; Shanley, J.B.; Vermilyea, A.; Sleeper, R.; Gold, A.J.; Pradhanang, S.M.; Inamdar, S.P.; Levia, D.F.; Andres, A.S.; et al. High-frequency dissolved organic carbon and nitrate measurements reveal differences in storm hysteresis and loading in relation to land cover and seasonality. Water Resour. Res. 2017, 53, 5345-5363. [CrossRef]

28. Stevens, A.A.; Moore, L.A.; Miltner, R.J. Formation and control of non-trihalomethane disinfection by-products. J. Am. Water Works Assoc. 1989, 81, 54-60. Available online: https://www.jstor.org/stable/41292790 (accessed on 23 June 2019). [CrossRef]

29. AWWA. Water chlorination/chloramination practices and principles. AWWA Man. 2006, 2, 1-188.

30. Bond, T.; Goslan, E.H.; Parsons, S.A.; Jefferson, B. A critical review of trihalomethane and haloacetic acid formation from natural organic matter surrogates. Environ. Technol. Rev. 2012, 1, 93-113. [CrossRef]

31. Community Water Treatment. Available online: https://www.cdc.gov/healthywater/drinking/public/water_ treatment.html (accessed on 23 June 2019).

32. Hanigan, D.; Zhang, J.; Herckes, P.; Krasner, S.W.; Chen, C.; Westerhoff, P. Adsorption of $\mathrm{N}$-nitrosodimethylamine precursors by powdered and granular activated carbon. Environ. Sci. Technol. 2012, 46, 12630-12639. [CrossRef]

33. Leavey-Roback, S.L.; Sugar, C.A.; Krasner, S.W.; Suffet, I.H. NDMA formation during drinking water treatment: A multivariate analysis of factors influencing formation. Water Res. 2016, 95, 300-309. [CrossRef] 
34. Frazar, S.; Gold, A.J.; Addy, K.; Moatar, F.; Birgand, F.; Schroth, A.; Kellogg, D.Q. Contrasting behavior of nitrate and phosphate flux from high flow events on small agricultural and urban watersheds. Biogeochemistry 2019, in press. [CrossRef]

35. Chambers, B.M.; Pradhanang, S.M.; Gold, A.J. Simulating climate change induced thermal stress in coldwater fish habitat using SWAT model. Water 2017, 9, 732. [CrossRef]

36. Climate Information. Available online: https://www.ncdc.noaa.gov/climate-information (accessed on 24 June 2019).

37. Silva, M.K.; Wada, T.K. Study of the formation of stable high concentrated monochloramine solutions. Syst. Eng. 2016, 2, 1-9.

38. Kodamatani, H.; Yamazaki, S.; Saito, K.; Amponsaa-Karikari, A.; Kishikawa, N.; Kuroda, N.; Tomiyasu, T.; Komatsu, Y. Highly sensitive method for determination of $\mathrm{N}$-nitrosamines using high-performance liquid chromatography with online UV irradiation and luminol chemiluminescence detection. J. Chromatogr. A 2009, 1216, 92-98. [CrossRef] [PubMed]

39. Kodamatani, H.; Roback, S.L.; Plumlee, M.H.; Ishida, K.P.; Masunaga, H.; Maruyama, N.; Fujioka, T. An inline ion-exchange system in a chemiluminescence-based analyzer for direct analysis of N-Nitrosamines in treated wastewater. J. Chromatogr. A 2018, 1553, 51-56. [CrossRef] [PubMed]

40. Fujioka, T.; Takeuchi, H.; Tanaka, H.; Nghiem, L.D.; Ishida, K.P.; Kodamatani, H. A rapid and reliable technique for $\mathrm{N}$-nitrosodimethylamine analysis in reclaimed water by HPLC-photochemical reaction-chemiluminescence. Chemosphere 2016, 161, 104-111. [CrossRef] [PubMed]

41. Gerecke, A.C.; Sedlak, D.L. Precursors of N-nitrosodimethylamine in natural waters. Environ. Sci. Technol. 2003, 37, 1331-1336. [CrossRef]

42. West, D.M.; Wu, Q.; Donovan, A.; Shi, H.; Ma, Y.; Jiang, H.; Wang, J. N-nitrosamine formation by monochloramine, free chlorine, and peracetic acid disinfection with presence of amine precursors in drinking water system. Chemosphere 2016, 153, 521-527. [CrossRef] [PubMed]

43. Najm, I.; Trussell, R. NDMA formation in water and wastewater. J. Am. Water Works Assoc. 2001, 93, 92-99. [CrossRef]

44. Charrois, J.W.A.; Boyd, J.M.; Froese, K.L.; Hrudey, S.E. Occurrence of N-nitrosamines in Alberta public drinking-water distribution systems. J. Environ. Eng. Sci. 2007, 6, 103-114. [CrossRef]

45. Zhao, Y.; Boyd, J.M.; Woodbeck, M.; Andrews, R.C.; Qin, F.; Hrudey, S.E.; Li, X. Formation of N-nitrosamines from eleven disinfection treatments of seven different surface waters. Environ. Sci. Technol. 2008, 42, 4857-4862. [CrossRef]

46. Farré, M.J.; Jaén-Gil, A.; Hawkes, J.; Petrovic, M.; Catalán, N. Orbitrap molecular fingerprint of dissolved organic matter in natural waters and its relationship with NDMA formation potential. Sci. Total Environ. 2019, 670, 1019-1027. [CrossRef]

47. Inamdar, S.; Finger, N.; Singh, S.; Mitchell, M.; Levia, D.; Bais, H.; Scott, D.; McHale, P. Dissolved organic matter (DOM) concentration and quality in a forested mid-Atlantic watershed, USA. Biogeochemistry 2012, 108, 55-76. [CrossRef]

48. Yoon, B.; Raymond, P.A. Dissolved organic matter export from a forested watershed during Hurricane Irene. Geophys. Res. Lett. 2012, 39, 1-6. [CrossRef]

49. Singh, S.; Inamdar, S.; Mitchell, M.; McHale, P. Seasonal pattern of dissolved organic matter (DOM) in watershed sources: Influence of hydrologic flow paths and autumn leaf fall. Biogeochemistry 2014, 118, 321-337. [CrossRef]

50. Duan, S.; Delaney-Newcomb, K.; Kaushal, S.S.; Findlay, S.E.G.; Belt, K.T. Potential effects of leaf litter on water quality in urban watersheds. Biogeochemistry 2014, 121, 61-80. [CrossRef]

51. Lusk, M.G.; Toor, G. Dissolved organic nitrogen in urban streams: Biodegradability and molecular composition studies. Water Res. 2016, 96, 225-235. [CrossRef] [PubMed]

52. Chiang, P.C.; Chang, E.E.; Liang, C.H. NOM characteristics and treatabilities of ozonation processes. Chemosphere 2002, 46, 929-936. [CrossRef]

53. Chen, C.; Zhang, X.; Zhu, L.; He, W.; Han, H. Changes in different organic matter fractions during conventional treatment and advanced treatment. J. Environ. Sci. 2011, 23, 582-586. [CrossRef]

54. Qualls, R.G.; Haines, B.L. Geochemistry of dissolved organic nutrients in water percolating through a forest ecosystem. Soil Sci. Soc. Am. J. 1991, 55, 1112-1123. [CrossRef] 
55. Yu, Z.; Zhang, Q.; Kraus, T.E.C.; Dahlgren, R.A.; Anastasio, C.; Zasoski, R.J. Contribution of amino compounds to dissolved organic nitrogen in forest soils. Biogeochemistry 2002, 61, 173-198. [CrossRef]

56. U.S. EPA. Finished Water Storage Facilities; Office of Ground and Drinking Water: Washington DC, USA, 2002; pp. 1-22. 